\title{
Methanolic Bark Extract of Abroma augusta (L.) Induces Apoptosis in EAC Cells through Altered Expression of Apoptosis Regulatory Genes
}

\author{
Masum Miah, Ajmeri Sultana Shimu (D), Shafi Mahmud, Farjana-Binta Omar, \\ Ratna Khatun, Sumon Chandro Mohanto, Kazi Md. Faisal Hoque, and Md. Abu Reza \\ Molecular Biology and Protein Science Laboratory, Department of Genetic Engineering and Biotechnology, \\ University of Rajshahi, Rajshahi 6205, Bangladesh \\ Correspondence should be addressed to Md. Abu Reza; reza.gen@ru.ac.bd
}

Received 17 December 2019; Revised 18 February 2020; Accepted 21 March 2020; Published 14 April 2020

Guest Editor: Reggiani Vilela Gonçalves

Copyright (C) 2020 Masum Miah et al. This is an open access article distributed under the Creative Commons Attribution License, which permits unrestricted use, distribution, and reproduction in any medium, provided the original work is properly cited.

\begin{abstract}
Abroma augusta (L.), one of the herbal medicinal plants, is widely used for treatment of various maladies. The present study was initiated to determine the antioxidant, hemolytic, cytotoxicity, and anticancer activities of methanolic extract from the bark of the plant. The phytochemical screening was done by analyzing different phytochemicals present in the extract. We observed the presence of alkaloids, steroids, terpenoids, flavonoids, reducing sugars, and glycosides in the bark extract which showed the highest antioxidant capacity. Antioxidant potential of the methanolic extract was evaluated in vitro by DPPH (2,2-diphenyl-1picrylhydrazyl) scavenging assay method. This extract showed prominent scavenging activity with $\mathrm{IC}_{50}$ value of $38.65 \mu \mathrm{g} / \mathrm{ml}$. The hemolytic activity of the extract was evaluated at concentrations ranging from 250 to $1000 \mu \mathrm{g} / \mathrm{ml}$. It was observed that the extract induced hemolysis percentage of $9.41 \%$ to $4.1 \%$, which implies that the extract has no potent hemolytic activity. Cytotoxicity and anticancer activities were observed on Ehrlich ascites carcinoma (EAC) cells. In addition, the bark showed promising cytotoxicity with $\mathrm{IC}_{50}$ value of $329.41 \mu \mathrm{g} / \mathrm{ml}$, and the study indicated that the extract was capable of inhibiting EAC cell growth by $75.5 \%$ when administered at $100 \mathrm{mg} / \mathrm{kg} /$ day body weight intraperitoneally for five consecutive days to Swiss albino mice. Morphological change of apoptotic cell was determined by fluorescence and optical microscopy. DNA fragmentation is another marker for apoptosis, and the bark extract-treated EAC cells showed smeared and fragmented DNA bands. Apoptosis correlated well with the upregulation of $\mathrm{p} 53$ and Bax and also with the downregulation of NF- $\kappa \mathrm{B}$ and Bcl-2. Furthermore, activity and interaction of two $A$. augusta compounds were tested through molecular docking simulation study. In conclusion, our results suggest that $A$. augusta bark has the potential to be considered as an anticancer agent.
\end{abstract}

\section{Introduction}

Cancer is an attenuating disease that is known as one of the major health problems of global concern and accounts for an estimated 9.6 million deaths in 2018 [1,2]. Generally, cancer refers to any one of a large number of diseases characterized by abnormal cell growth with the potential to invade other normal cells of the body. The current treatment options for cancer include chemotherapy, radiotherapy, and chemically derived drugs; those are generally nonspecific, cause toxicity, damage normal cell, and even lead to death [3]. According to the World Health Organization, about $65 \%$ of the global population tend to choose traditional herbal medicines to treat various diseases like cancer, diabetes, and hepatic disorder because of their availability, absence of adverse effects, and cost effectiveness [4]. Scientists are constantly in search of phytochemicals from medicinal plants with unique features to develop novel drugs against cancer in contrast to conventional chemotherapy, radiotherapy, and surgery to diminish adverse side effects $[5,6]$. Earlier reports show that some plant-derived natural phytochemicals have promising anticancer potential and ability to reduce the growth of specific tumor cells [7].

Apoptosis plays vital roles in a broad sense of physiological processes during fetal development as well as in adult 
tissues. Apoptosis takes place through differential regulation of various types of proapoptotic and antiapoptotic genes [8]. Stirring of cell morphology via chromatin condensation and nuclear fragmentation, plasma membrane blebbing, and cell shrinkage are the hallmarks of apoptosis [9]. During cancer formation, expression of antiapoptotic genes is upregulated, whereas proapoptotic genes are downregulated and thus cells escape apoptosis to become cancerous. Proapoptotic p53, Bax signaling and antiapoptotic Bcl-2, NF- $\kappa$ B signaling play critical roles in tumor development and progression and are involved in angiogenesis, metastasis, and cell survival $[10,11]$.

Antioxidants are substances that scavenge free radicals and protect oxidative damage by neutralizing the reactive oxygen species (ROS) [12]. Overproduction of ROS contributes to oxidative stress in the human body, which leads to damage of proteins, lipids, and DNA that is associated with chronic degenerative diseases such as hypertension, coronary artery diseases, diabetes, and cancer [13]. Photochemical derived from plants contain phenolics, flavonoids, alkaloids, and tannins, which may possess high antioxidant activity and also may protect the body from several degenerative disorders [14].

A. augusta (L.) (family: Sterculiaceae or Malvaceae in some classifications) is commonly known as Ulatkambal in Bengali and Hindi, and Devil's cotton in English. It is an evergreen small shrub with a long history of medicinal uses and mostly found in tropical Asia, South Eastern Africa, and Australia [15]. In India, the mother tincture of A. augusta is widely used in homeopathic medicine to treat uterine disorders and diabetes mellitus $[16,17]$. Its root-bark is highly useful as uterine tonic and is used to treat amenorrhoea and dysmenorrhea, with abortifacient and antifertility activities, whereas leaves are used for diabetes, rheumatic pains, gonorrhea, headache, and sinusitis [18]. However, the anticancer potential of this medicinal plant is still unrevealed and no advanced molecular study of gene-mediated oncogenic pathway was conducted so far. Therefore, the current study aims to investigate the anticancer potential of $A$. augusta and the molecular pathway through which it induces apoptosis of cancer cells. The study is again strongly supported by molecular docking study of $A$. augusta derived molecules interacting with $\mathrm{Bcl}-2$ and $\mathrm{NF}-\kappa \mathrm{B}$ gene.

\section{Materials and Methods}

2.1. Collection of Plants Material. The bark of the A. augusta was collected from the Shah Sufi Mosque, Chhatak, Sylhet, Bangladesh, during July 2017 (latitude: $25^{\circ} 02^{\prime} 30.12^{\prime \prime} \mathrm{N}$, longitude: $\left.91^{\circ} 40^{\prime} 30.00^{\prime \prime} \mathrm{E}\right)$. The identity of the plant was authenticated by Professor Dr. AHM Mahbubur Rahman, taxonomist in the Department of Botany, University of Rajshahi, Bangladesh, where a voucher specimen (Accession number: 17) was deposited.

2.2. Chemicals and Reagents. Methanol, 2,2-diphenyl-1picrylhydrazyl (DPPH), potassium ferricyanide, phosphate buffer, catechin (CA), ferrous ammonium sulphate, butylated hydroxytoluene (BHT), gallic acid (GA), and $\mathrm{FeCl}_{3}$ were purchased from Sigma Aldrich Chemical Co. (St. Louis, MO, USA); Folin-Ciocalteu phenol reagent (FCR), trypan blue dye, DAPI, DMSO, and sodium carbonate were obtained from Merck (Darmstadt, Germany); 2',7'-dichlorofluorescein diacetate was acquired from Sigma Aldrich (USA). RNAsimple total RNA kit, M-MLV reverse transcriptase, dNTPs, and oligo (dT) primers were purchased from TIANGEN Biotech (Beijing, China); primers for GAPDH, p53, Bax, Bcl-2, and NF- $\kappa$ B were custom-synthesized from IDT, Malaysia.

2.3. Preparation of Plant Extract. A. augusta bark sample was thoroughly washed with distilled water and shade-dried for 7 days with occasional sun drying. The dried materials were ground into fine powder using a mechanical grinder and stored at room temperature (RT) for future use. $100 \mathrm{gm}$ of bark powder was immersed in $500 \mathrm{ml}$ methanol and shaked at $200 \mathrm{rpm}$ for 24 hours by shaking incubator (HYSC, Hanyang Scientific Equipment Co., Ltd., Seoul, Korea). Then, the solution was filtered through Whatman No. 1 filter papers and concentrated with a rotary evaporator. Finally, the whole solvent was evaporated using freeze dryer. The extract was then kept in glass vial with airtight caps and stored at $4^{\circ} \mathrm{C}$.

2.4. Qualitative Phytochemical Screening. The methanolic extract was used to perform the phytochemical screening according to the methods described by Sofowora and Trease and Evans [19, 20].

2.5. Determination of Total Phenolics. Total phenolic contents of the extracts were determined by Folin-Ciocalteu method described by Machu et al. [21]. In brief, an aliquot of the extracts, $300 \mu \mathrm{l}(1 \mathrm{mg} / \mathrm{ml} \mathrm{DW})$, was mixed with $2.25 \mathrm{ml}$ Folin-Ciocalteu reagent (previously diluted with water $1: 10$ $\mathrm{v} / \mathrm{v})$ and $2.25 \mathrm{~mL}(75 \mathrm{~g} / \mathrm{L})$ of sodium carbonate. The tubes were vortexed thoroughly for $15 \mathrm{~s}$ and allowed to stand for $90 \mathrm{~min}$ at $25^{\circ} \mathrm{C}$ for color development. Absorbance was then measured at $725 \mathrm{~nm}$ in a UV-Vis spectrophotometer (GENESYS 10S, Thermo Scientific, USA). Samples of extracts/standard were evaluated at a final concentration of $1 \mathrm{mg} / \mathrm{ml}$. Total phenolic contents were expressed in terms of gallic acid equivalent (GAE) (standard curve equation: $\left.y=0.003 x-0.002, R^{2}=0.990\right)$, mg of GAE/g of dry extract.

2.6. Determination of Total Flavonoids. Total flavonoid contents were estimated using aluminum chloride colorimetric assay method described by Kiranmai et al. [22]. $150 \mu \mathrm{l}$ of $5 \%$ sodium nitrate and $2.5 \mathrm{~mL}$ of distilled water were added to $0.5 \mathrm{ml}$ of crude extract $(1 \mathrm{mg} / \mathrm{ml} \mathrm{DW})$ into a microcentrifuge tube. After $6 \mathrm{~min}, 0.3 \mathrm{ml}$ of $10 \% \mathrm{AlCl}_{3}$ was added and the mixture was allowed to stand for $5 \mathrm{~min}$ followed by addition of $1 \mathrm{~mol} / \mathrm{l} \mathrm{NaOH}$ solution. The mixture was thoroughly mixed using vortex and the absorbance of the mixtures was measured at $510 \mathrm{~nm}$. Total flavonoid contents were expressed in terms of catechin equivalent 
(CAE) (standard curve equation: $y=0.004 x-0.054$, $\left.R^{2}=0.990\right)$, mg of CAE/g of dry extract.

2.7. DPPH Free Radical Scavenging Assay. Free radical scavenging ability of the extract was determined according to Matkowski and Piotrowska [23]. $10 \mathrm{mg}$ DPPH was dissolved in $100 \mathrm{ml}$ methanol $(\mathrm{MeOH})$ to obtain a concentration of $100 \mu \mathrm{g} / \mathrm{ml}$. The stock solution of the extracts was prepared by dissolving $1 \mathrm{mg}$ freeze-dried extract in $1 \mathrm{ml}$ $\mathrm{MeOH}$. Dilutions of the stock solutions were prepared to obtain concentrations of $25 \mu \mathrm{g} / \mathrm{ml}, 50 \mu \mathrm{g} / \mathrm{ml}, 100 \mu \mathrm{g} / \mathrm{ml}$, $150 \mu \mathrm{g} / \mathrm{ml}$, and $200 \mu \mathrm{g} / \mathrm{ml}$, while the control was prepared by dissolving $1 \mathrm{ml} \mathrm{DPPH}$ in $1 \mathrm{ml} \mathrm{MeOH}$ (without sample). $1.5 \mathrm{ml}$ methanol solution of DPPH was added to each solution, and the solution was kept in dark for $30 \mathrm{~min}$. The absorbance of the solution was measured spectrophotometrically at $517 \mathrm{~nm}$, and BHT was used as standard. The percentage of DPPH radical scavenging activity was calculated by the following equation:

$$
\% \mathrm{DPPH} \text { radical scavenging activity }=\frac{\left(A_{0}-A_{1}\right)}{A_{0}} \times 100 \text {, }
$$

where $A_{0}$ is the absorbance of the control and $A_{1}$ is the absorbance of the extracts. Then, the percentage of inhibition was plotted against concentration, and from the graph $\mathrm{IC}_{50}$ was calculated.

2.8. Experimental Animals. A total of 24 mature female Swiss albino mice (25-30 g) were collected from the Department of Pharmacy of Jahangirnagar University, Dhaka, Bangladesh. These animals were kept in standard laboratory conditions (temperature $25 \pm 2^{\circ} \mathrm{C}$; humidity $55 \pm 5 \%$ ) with $12 \mathrm{~h}$ dark/light cycle throughout the whole study. To keep the hydration rate constant, food and water supply were stopped 12 hours before the experiment.

2.9. Ethical Approval. The current experimental procedure was approved by the Institutional Animal, Medical Ethics, Biosafety and Biosecurity Committee (IAMEBBC) for Experimentations on Animal, Human, Microbes and Living Natural Sources, Institute of Biological Sciences, University of Rajshahi, Bangladesh (Approval no.: 225/320-IAMEBBC/ IBSc).

2.10. Transplantation of Tumor. Ehrlich ascites carcinoma (EAC) cells were obtained from Indian Institute of Chemical Biology, Kolkata, India. The EAC cells culture and aspiration were maintained according to method of Alam [24]. In brief, in vivo cultured EAC cells were drawn out from 6- to 7-dayold ascites tumors of EAC tumor-bearing mice. The drawn cells were diluted with $0.9 \%$ normal saline. After dilution, the numbers of EAC cells were adjusted to approximately $1 \times 10^{6}$ cells $/ \mathrm{ml}$ by counting the cell number with the help of a hemocytometer. Each animal received $0.1 \mathrm{ml}$ of tumor cell suspension containing $1 \times 10^{6}$ tumor cells intraperitoneally.
2.11. Acute Toxicity Study. The acute toxicity was studied by administering $1000 \mathrm{mg} / \mathrm{kg} \mathrm{b}$. wt oral dose of the A. augusta bark extract as described earlier [25]. No mortality was observed during the study. On the basis of this study, the doses of 50 and $100 \mathrm{mg} / \mathrm{kg} \mathrm{b.} \mathrm{wt/day} \mathrm{(i.p.)} \mathrm{were} \mathrm{selected} \mathrm{for}$ A. augusta.

2.12. Hemolytic Activity. Hemolytic activity of methanolic bark extract of $A$. augusta was assayed on goat erythrocytes following the method of Henkelman et al. [26]. In brief, $5 \mathrm{ml}$ of blood was obtained from healthy goat in tubes containing $3.8 \%$ trisodium citrate and centrifuged at 5,000 rpm for $20 \mathrm{~min}$. The supernatant was discarded by micropipette, and afterwards the blood cells were washed two times with $0.9 \%$ $\mathrm{NaCl}$ at 5,000 rpm for $15 \mathrm{~min}$ to prepare $10 \% \mathrm{RBC}$. $150 \mu \mathrm{l}$ of $10 \%$ RBC suspension was mixed with 25,50 , and $100 \mu \mathrm{l}$ of test samples $(10 \mathrm{mg} / \mathrm{ml})$. Two controls were prepared without extract; negative control received $1350 \mu \mathrm{l}$ of $0.9 \%$ $\mathrm{NaCl}$, while positive control received $1350 \mu \mathrm{l}$ of $\mathrm{dH}_{2} \mathrm{O}$; reaction mixture was incubated at $37^{\circ} \mathrm{C}$ in a water bath for $60 \mathrm{~min}$. The volume of the reaction mixture was diluted to $1.5 \mathrm{ml}$ by adding $0.9 \% \mathrm{NaCl}$. Finally, it was centrifuged at $3000 \mathrm{rpm}$ for $5 \mathrm{~min}$, and the resultant hemoglobin concentration in the supernatant was spectrophotometrically measured at $540 \mathrm{~nm}$. The percentage of hemolysis was calculated by dividing sample absorbance on positive control absorbance (complete hemolysis) multiplied by 100 .

2.13. MTT Assay. Cytotoxic activity of bark extract of $A$. augusta was evaluated in 96-well microtiter plates against EAC cell by MTT (3-[4, 5-dimethylthiazol-2-yl]-2,5diphenyl tetrazolium bromide) colorimetric assay [27]. For experiment, $200 \mu \mathrm{l}$ of EAC cells $\left(1 \times 10^{6}\right.$ cells $)$ cultured in RPMI-1640 media was taken in each well of a 96-well culture plate at different concentrations (500, 250, 125, 62.5, and $31.25 \mu \mathrm{g} / \mathrm{ml}$ ) of extract. Culture plate was then placed in $\mathrm{CO}_{2}$ incubator at $37^{\circ} \mathrm{C}$ with constant flow of $5 \% \mathrm{CO}_{2}$ for 1 day followed by the removal of supernatant. After addition of $180 \mu \mathrm{l}$ of PBS and $20 \mu \mathrm{l}$ of MTT to each well of the culture plate, they were incubated at $37^{\circ} \mathrm{C}$ for an additional 8 hours. The supernatant was removed again and $200 \mu \mathrm{l}$ of acidic isopropanol was put into each well followed by incubation at $37^{\circ} \mathrm{C}$ for 1 hour. The plate was read at $570 \mathrm{~nm}$ on a multiwell plate reader (Multiskan $^{\mathrm{TM}}$ FC Microplate Photometer, Thermo Scientific, Waltham, MA, USA). The following equation was used to calculate the cell proliferation inhibition ratio:

$$
\text { proliferation inhibition ratio }(\%)=\left[\frac{(A-B)}{A}\right] \times 100 \text {, }
$$

where $A$ and $B$ denote the absorbance $\mathrm{OD}_{570} \mathrm{~nm}$ of the cellular homogenate in the absence and presence of the bark extract, respectively.

2.14. Determination of Cell Growth Inhibition (In Vivo). To evaluate the cell growth inhibition [28] of bark extract of A. augusta, four groups of Swiss albino mice $(n=6)$ were 
used. For therapeutic evaluation, $1 \times 10^{6}$ EAC cells were inoculated in every mouse on day 0 . Treatments were started after $24 \mathrm{~h}$ of tumor inoculation and continued for 5 days. Group one was used as control. Group two received bleomycin (standard anticancer drug) at the dose of $0.3 \mathrm{mg} / \mathrm{kg} /$ day. Group three received the bark extract at the dose of $50 \mathrm{mg} / \mathrm{kg}$ (i.p.). Group four received the bark extract at the dose of $100 \mathrm{mg} / \mathrm{kg}$ (i.p.). Mice in each group were sacrificed on day six and total intraperitoneal tumor cells were harvested by normal saline $(0.98 \%)$. Viable cells of EAC cells of both treated and control mice were first identified by using trypan blue and then counted by a hemocytometer. The cell growth inhibition was calculated using the following formula:

$$
\% \text { cell growth inhibition }=\left(\frac{1-T_{w}}{C_{w}}\right) \times 100,
$$

where $T_{w}$ is the mean number of EAC cells in treated mice and $C_{w}$ is the mean number of EAC cells in control mice.

2.15. DAPIStaining for Apoptosis Assessment. EAC cells were collected from both treated and control mice after 5 consecutive days of treatment [29]. DAPI $(0.1 \mu \mathrm{g} / \mathrm{ml})$ was used for staining the cells at $37^{\circ} \mathrm{C}$ for $15 \mathrm{~min}$ in dark condition. Washing and resuspension were carried out by PBS in order to find out morphological alterations. Moreover, $5 \mu \mathrm{l} \mathrm{su-}$ pernatant was taken on a microscopic slide and cellular changes were observed under the fluorescence microscope (Olympus IX71, Korea).

2.16. DNA Fragmentation Assay. The effect of the extract on DNA fragmentation was determined by previously described method [30]. After 5 consecutive days of treatment, both treated and control EAC cells were collected. Genomic DNA was isolated from the cells by using TIANamp Genomic DNA kit (TIANGEN Biotech, Beijing, China), and the DNA was analyzed on $1 \%$ agarose gel under gel documentation system (Alphaimager Mini System, ProteinSimple).

2.17. Determination of Intracellular ROS Generation. By using $2,7^{\prime}$-dichlorodihydrofluorescein diacetate (DCF-DA), intracellular reactive oxygen species (ROS) levels of living cells were measured as described previously [31]. The EAC cells-bearing mice were treated with bark extract of $A$. augusta, and on the $6^{\text {th }}$ day mice were sacrificed and tumor cells were collected. Treated and untreated cells were incubated with DCF-DA $(50 \mu \mathrm{M})$ as the fluorescence agent for $30 \mathrm{~min}$ at $37^{\circ} \mathrm{C}$ and subsequently washed with PBS. The fluorescence was monitored by an inverted fluorescent microscope (Olympus IX71, Korea) at an excitation and emission wave length of $485 \mathrm{~nm}$ and $530 \mathrm{~nm}$, respectively.

2.18. RNA Isolation, cDNA Synthesis, and PCR Amplification of $p 53, B a x, B c l-2$, and $N F-\kappa B$. Total RNA was extracted from EAC cells collected from mice of untreated and treated $(100 \mathrm{mg} / \mathrm{kg} /$ day $)$ groups on the sixth day after EAC cell implantation using TIANGEN reagent kit. RNA was quantified using a nanodrop (Thermo Scientific, Waltham, Massachusetts, USA). RNA was also run on a formamide gel to check the quality in visual way. cDNA synthesis was carried out using reverse transcription reaction mixture $(20 \mu \mathrm{l})$, containing $2 \mu \mathrm{l}$ oligo (dT), $1 \mu \mathrm{l}$ M-MLV reverse transcriptase, $2 \mu \mathrm{l}$ dNTPs, $4 \mu \mathrm{l} 5 \times 1^{\text {st }}$ strand buffer, and $3 \mu \mathrm{l}$ total RNA sample; $8 \mu \mathrm{l} \mathrm{dH_{2 }}$ O. $2 \mu \mathrm{g}$ of total RNA was reverse-transcribed into cDNA in a $20 \mu \mathrm{l}$ reaction mixture containing $2 \mu \mathrm{l}$ oligo (dT), $1 \mu \mathrm{l}$ M-MLV reverse transcriptase, $2 \mu \mathrm{l}$ dNTPs, $4 \mu \mathrm{l} 5 \times$ $1^{\text {st }}$ strand buffer, and required amount of deionized water. Relative expression of the cancer genes was investigated using the primer pairs in Table 1. The primers (IDT, Singapore) were designed based on previous report [24].

2.19. Brine Shrimp Lethality Bioassay. Cytotoxicity of the bark extract of A. augusta was screened against Artemia salina according to published protocol [34]. For the experiment, $1 \mathrm{mg}$ of the bark extract was dissolved in $1 \mathrm{ml}$ $(1000 \mu \mathrm{l})$ of distilled water to get a concentration of $1 \mu \mathrm{g} / \mu \mathrm{l}$, in addition to serial dilution. Various concentrations of bark extract such as $25,50,75,100,150$, and $200 \mu \mathrm{g} / \mathrm{mL}$ were obtained. After $24 \mathrm{~h}$ of incubation, the percentage of mortality of the nauplii was calculated for each concentration and the $\mathrm{LD}_{50}$ value was determined by using probit analysis.

2.20. Ligand Preparation. Reported structures of photochemical compounds from A. augusta (CID-72, CID-247, CID-305, CID-8468, CID-73170, CID-73659) were retrieved from PubChem database as SDF format [33]. To remove clashes among the atoms of the ligands, energy minimization was carried out using YASARA server by utilizing YASARA software [34].

2.21. Protein Preparation. Crystal structure of Bcl-2 and NF$\kappa \mathrm{B}$ protein was retrieved from Protein Data Bank database [35] with their respective PDB ID (PDB-2W3L and 1SVC). Energy minimization of the protein was done through SwissPdbViewer software [36]. Improper bonding, missing hydrogen, and side chain geometry were checked. PyMOL software package [37] was used to remove water molecules and hetero atoms. Finally, protein and ligand were saved as PDBQT format which is the only supported file in AutoDock Vina [38].

2.22. Pharmacokinetic Parameter. admetSAR [39] and SwissADME [40] web servers were utilized to access the information of compound metabolism, carcinogenicity, and Lipinski filtering. Structure-data file (SDF) and simplified molecular-input line-entry system (SMILES) were used as input system to unlock pharmacological properties of the ligand.

2.23. Docking. After ADMET screening, compounds were subjected to molecular docking in AutoDock Vina. Crystal structures of Bcl-2 and NF- $\kappa \mathrm{B}$ were used as micromolecules 
TABLE 1: The primer used for PCR amplification.

\begin{tabular}{|c|c|c|}
\hline Gene & Primer sequence & Amplification size \\
\hline GAPDH & $\begin{array}{c}\text { Forward: 5'-GTGGAAGGACTCATGACCACAG-3' } \\
\text { Reverse: } 5^{\prime} \text {-CTGGTGCTCAGTGTAGCCCAG-3 }{ }^{\prime}\end{array}$ & $350 \mathrm{bp}$ \\
\hline p53 & $\begin{array}{l}\text { Forward: 5'-GCGTCTTAGAGACAGTTGCCT-3' } \\
\text { Reverse: } 5^{\prime} \text {-GGATAGGTCGGCGGTTCATGC-3' }\end{array}$ & $450 \mathrm{bp}$ \\
\hline Bax & $\begin{array}{l}\text { Forward: } 5^{\prime} \text {-GGCCCACCAGCTCTGAGCAGA-3' } \\
\text { Reverse: } 5^{\prime} \text {-GCCACGTGGGCGTCCCAAAGT-3' }\end{array}$ & $500 \mathrm{bp}$ \\
\hline Bcl-2 & $\begin{array}{l}\text { Forward: } 5^{\prime} \text {-GTGGAGGAGCTCTTCAGGGA-3' } \\
\text { Reverse: } 5^{\prime} \text {-AGGCACCCAGGGTGATGCAA-3' }\end{array}$ & $250 \mathrm{bp}$ \\
\hline$N F-\kappa B$ & $\begin{array}{l}\text { Forward: 5'-AACAAAATGCCCCACGGTTA-3' } \\
\text { Reverse: } 5^{\prime} \text {-GGGACGATGCAATGGACTGT-3' }\end{array}$ & $125 \mathrm{bp}$ \\
\hline
\end{tabular}

for docking study. Energy minimization was done by universal force field (UFF) and conjugated gradient algorithm. The total number of steps and the number of steps for update were set as defaults [41]. In molecular docking process, the center grid box was set at $X: 42.336, Y: 26.3284, Z: 35.9666$ and box size was $X: 827210, Y: 70.1628, Z: 64.1580$ for NF- $\kappa \mathrm{B}$ protein (Table 2). On the other hand, for Bcl-2 protein, center grid box was set at $X ; 47.3586, Y: 33.2146, Z:-5.4377$ and box size was $X: 50.00, Y: 45.64, Z: 42.3887$ (Table 3). In addition, known inhibitors bleomycin was used in this study as control in docking study. This FDA approved drug was prepared and minimized by using previous method as described in ligand preparation section. MOE dock module of MOE-2015 software was used to cross-validate the docking score obtained from AutoDock Vina. Alpha Matcher placement and Alpha Triangle placement method were applied to dock into the active site of the protein. GBVI/ WSA dG with the force field refinement was used to predict binding affinity. Hydrophobic interaction, hydrogen bonding which was responsible for the protein and ligand interaction, and these interactions were assessed through Discovery Studio [42] and PyMOL [43].

2.24. Statistical Analysis. Data were represented as mean\pm standard deviation (SD) for triplicate experiments. Statistical analysis was performed by one-way ANOVA, and $p<0.05$ was considered as statistically significant. SPSS 16.0 software for Windows 10 was used for statistical analysis.

\section{Results}

3.1. Phytochemical Screening. The phytochemical screening test of A. augusta bark extract exhibited the presence of alkaloids, glycosides, reducing sugars, terpenoids, steroids, and flavonoids (Table 4 ), which is indicated by a positive sign $(+)$, while the absence of saponins and tannins is indicated by a negative sign (-).

3.2. Total Phenolic and Flavonoid Contents. Polyphenols are important compounds of plant due to their antioxidant nature and various diseases curing abilities. Therefore, the amount of total phenolic compounds and flavonoids from $A$. augusta bark was quantified as shown in Table 5.
3.3. DPPH Radical Scavenging Activity. Figure 1 shows free radical scavenging activity of $A$. augusta bark extract and standard BHT. The current study shows that the bark extract and standard BHT demonstrate almost equal amount of activity. The scavenging activity of bark extract at the highest concentration of $200 \mu \mathrm{g} / \mathrm{ml}$ was $93.32 \%$, whereas at the same concentration the activity of standard was $97.31 \%$. The $\mathrm{IC}_{50}$ value of bark extract and BHT standard was calculated to be $38.65 \mu \mathrm{g} / \mathrm{ml}$ and $57.29 \mu \mathrm{g} / \mathrm{ml}$, respectively. A higher $\mathrm{IC}_{50}$ value means lower radical scavenging activity. Hence, the free radical scavenging activity of bark extract is greater than that of BHT.

3.4. Hemolytic Activity. Human erythrocytes membranes from blood types show different stability as determined from the mean corpuscular fragility. Chemical agent can positively affect the red cell membrane, and on the contrary, many of them have severe undesirable effects, which induce hemolytic anemia. As bark extract is likely to be used as drug, it needs to be studied for its potential hemolytic activity. The hemolytic activity of the extract was evaluated at concentrations of $250 \mu \mathrm{g} / \mathrm{ml}, 500 \mu \mathrm{g} / \mathrm{ml}$, and $1000 \mu \mathrm{g} / \mathrm{ml}$ (Table 6). It was observed that the extract induced nonsignificant amount of hemolysis, which implies that the extract has no potent hemolytic activity.

3.5. MTT Assay. The study of cytotoxicity of bark extract against EAC cells is presented in Figure 2, which revealed that the A. augusta bark extract showed promising cytotoxic activity against cancer cell. $500 \mu \mathrm{g} / \mathrm{ml}, 250 \mu \mathrm{g} / \mathrm{ml}, 125 \mu \mathrm{g} / \mathrm{ml}$, $62.5 \mu \mathrm{g} / \mathrm{ml}$, and $31.25 \mu \mathrm{g} / \mathrm{ml}$ concentration of bark extract induced $64.89 \%, 49.64 \%, 34.30 \%, 15.55 \%$, and $4.69 \%$ cell death, respectively, against EAC cells. The $\mathrm{IC}_{50}$ value of bark extract of $A$. augusta was calculated as $329.41 \mu \mathrm{g} / \mathrm{ml}$.

3.6. Growth Inhibitory Activity of Bark Extract of A. augusta against EAC Cells. The antiproliferative activity of bark extract of $A$. augusta was observed using hemocytometer by counting EAC cells using trypan blue dye. Results show that the viability of EAC cells is considerably decreased in treated group in comparison with control (Table 7; Figure 3). Maximum cell growth inhibition (75.5\% reduction of tumor cells) was found with the treatment of bark extract at the dose of $100 \mathrm{mg} / \mathrm{kg}$ body weight (i.p.). 
TABLE 2: Binding energy, hydrogen bond, hydrophobic interaction, and binding distance of docked pose of NF- $\kappa \mathrm{B}$, with $\mathrm{kcal} / \mathrm{mol} \mathrm{used}$ as unit of binding affinity

\begin{tabular}{|c|c|c|c|c|}
\hline \multirow[t]{2}{*}{ Compound } & \multirow[t]{2}{*}{$\begin{array}{l}\text { Docking score } \\
\text { (kcal/mol) in } \\
\text { AutoDock }\end{array}$} & \multirow[t]{2}{*}{$\begin{array}{l}\text { Docking score } \\
\text { in MOE }\end{array}$} & H-bond interactions & Hydrophobic interactions \\
\hline & & & $\begin{array}{l}\text { Amino acids } \\
\text { distance }(\AA)\end{array}$ & Amino acids distance $(\AA)$ \\
\hline D1 & -7.2 & -11.28 & $\begin{array}{c}\text { Asn103 (2.08), His110 (2.09), Ser211 (2.29), Val212 } \\
\text { (2.55), Arg214 (2.56) }\end{array}$ & Val213 (2.86), Met208 (3.56) \\
\hline D2 & -7.9 & -11.75 & Ser113 (2.40), Arg157 (2.05), His112 (3.02) & Leu143 (4.52), Val145 (4.79) \\
\hline $\begin{array}{l}\text { D3 or } \\
\text { bleomycin }\end{array}$ & -7.8 & -10.78 & $\begin{array}{l}\text { Ser249 (2.74), Asn250 (2.02), Asp274 (2.72), Gly69 } \\
(2.80) \text {, Lys80 (2.73), Ser74 (2.31), sLys52 (2.25) }\end{array}$ & $\begin{array}{l}\text { Gly55 (3.73), Glu344 (3.21), } \\
\text { Lys79 (4.45), Lys80 (3.28) }\end{array}$ \\
\hline
\end{tabular}

TABLE 3: Binding energy, hydrogen bond, hydrophobic interaction, and binding distance of docked pose of Bcl-2, with kcal/mol used as unit of binding affinity.

\begin{tabular}{|c|c|c|c|c|}
\hline Compound & $\begin{array}{l}\text { Docking score } \\
(\mathrm{kcal} / \mathrm{mol}) \text { in } \\
\text { AutoDock }\end{array}$ & $\begin{array}{l}\text { Docking score } \\
\text { in MOE }\end{array}$ & H-bond interactions & Hydrophobic interactions \\
\hline & & & Amino acids distance $(\AA)$ & $\begin{array}{l}\text { Amino acids } \\
\text { distance }(\AA)\end{array}$ \\
\hline D1 & -7.9 & -11.29 & $\begin{array}{c}\operatorname{Arg} 86(2.3 \AA), \operatorname{Trp} 135(1.9 \AA) \\
\text { Glu138 }(2.2 \AA)\end{array}$ & Phe89 (5.1 ̊̊), Ala90 (5.1 ̊) \\
\hline D2 & -8.1 & -11.26 & $\begin{array}{c}\text { Ala90 (2.9 } \AA) \text {, Glu138 (2.4 } \AA) \text {, } \\
\operatorname{Trp} 135(2.5)\end{array}$ & Phe89 (5.1 ̊̊), Ala90 (5.1 Å) \\
\hline D3 & -7.7 & -10.75 & $\begin{array}{l}\text { Asn102 (2.40), Gly104 (2.59), } \\
\text { Tyr161 (2.05), Leu160 (2.40) }\end{array}$ & $\begin{array}{l}\text { Phe63 (3.23), Tyr67 (5.15), Ala108 (5.02), Ala59 } \\
\text { (4.47), Val107 (5.13), Arg105 (4.23), Ala108 (3.41) }\end{array}$ \\
\hline
\end{tabular}

TABLE 4: Results of phytochemical screening of A. augusta.

\begin{tabular}{lcc}
\hline Phytochemicals & Tests & A. augusta \\
\hline Alkaloids & Mayer's test & + \\
Saponins & Forth test & - \\
Glycosides & Keller-Kiliani test & + \\
Reducing sugars & Fehling test & + \\
Terpenoids & Salkowski's test & + \\
Steroids & Liebermann-Burchard test & + \\
Tannins & Ferric chloride test & - \\
Flavonoids & Ethyl acetate test & + \\
\hline
\end{tabular}

TABle 5: Polyphenol contents of the methanolic bark extract of A. augusta.

\begin{tabular}{lcc}
\hline Extract & Phenolics (GAE/g of dry extract) & Flavonoids (CAE/g of dry extract) \\
\hline A. augusta (bark) & $182.33 \pm 3.055$ & $81.33 \pm 2.081$ \\
\hline
\end{tabular}

Data are represented as mean $\pm \mathrm{SD}(n=3)$.

3.7. Detection of Apoptotic EAC Cells by DAPI Staining. To observe the morphological changes of EAC cells after five consecutive days of treatment, DAPI staining assay was performed. Treated cells showed different hallmarks of apoptosis which include shrunken nature of cell, condensation of chromatin, membrane blebbing, and nuclear fragmentation of apoptotic bodies when compared to the normal cells (Figure 4).

3.8. New Measurement of ROS Generation in EAC Cells. The ROS production in EAC cells was determined after 5 consecutive days of treatment. As shown in Figure 5, control cells showed faintly green fluorescence that indicates low level of ROS production showing that the ROS formation was of low level. The methanolic bark extract increased ROS generation in EAC cells in a concentration dependent manner. The ROS generation was increasing at higher concentration (50 and $100 \mathrm{mg} / \mathrm{kg} /$ day). In EAC cells, the highest ROS generation was observed at $100 \mathrm{mg} / \mathrm{kg} /$ day of bark extract of A. augusta. The result demonstrated that the A. augusta bark extract induced mitochondria-mediated apoptosis in EAC cells which may be related to ROS hypergeneration.

3.9. DNA Fragmentation Assay. The DNA fragmentation by agarose gel electrophoresis pattern of DNA from normal and bark extract-treated EAC cells is presented in Figure 6(a). In 


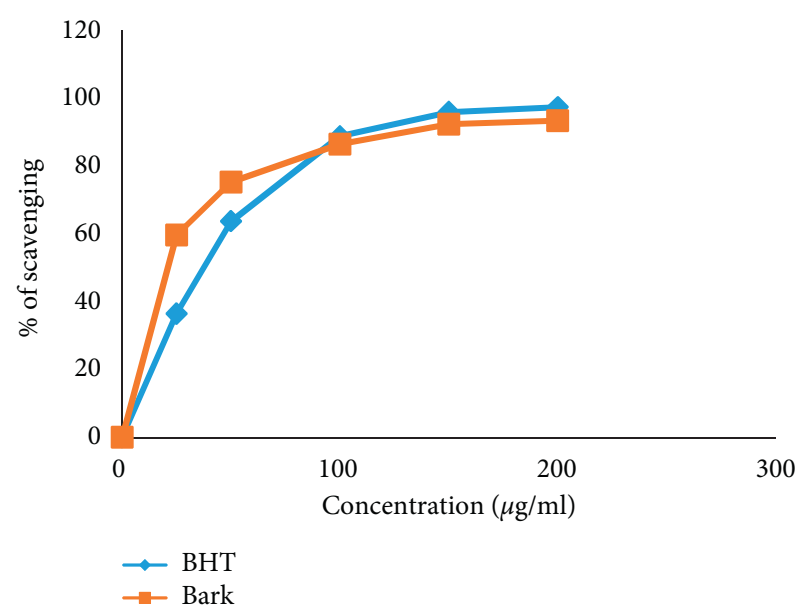

FIgURE 1: The antioxidant activity of bark extracts of A. augusta along with standard BHT. The scavenging percentage of DPPH by A. augusta at the concentration rate $(25-200 \mu \mathrm{g} / \mathrm{ml})$ as compared to BHT.

TABLe 6: Hemolytic assay of bark extract of A. augusta.

\begin{tabular}{lcc}
\hline Concentration $(\mu \mathrm{g} / \mathrm{ml})$ & Absorbance at $540 \mathrm{~nm}$ & $\%$ hemolysis \\
\hline Negative control & 0.045 & 0 \\
Positive control & 0.478 & 95.35 \\
250 & 0.045 & 9.41 \\
500 & 0.020 & 4.2 \\
1000 & 0.0196 & 4.1 \\
\hline
\end{tabular}

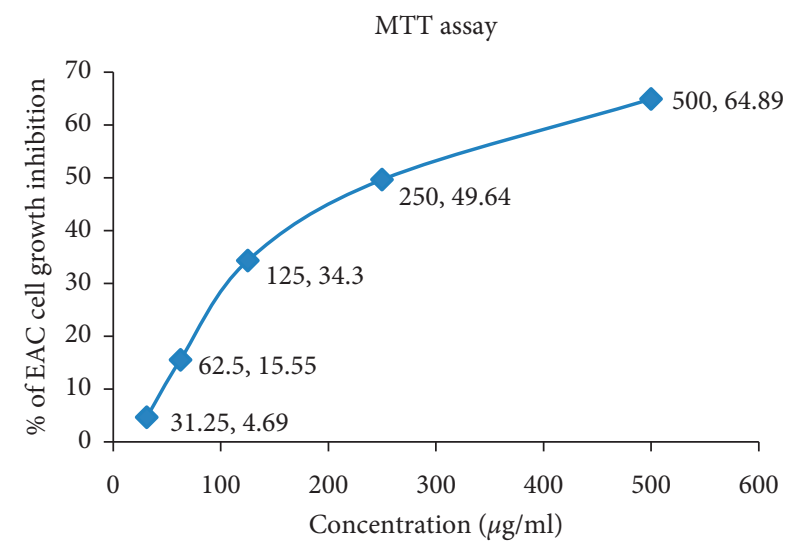

Figure 2: In vitro cell growth inhibition along with $\mathrm{IC}_{50}$ value of bark extract of A. augusta by MTT colorimetric assay. EAC cells were treated at different doses of bark extract for $24 \mathrm{~h}$ in RPMI1640 medium to evaluate the EAC cells growth inhibition, and $\mathrm{IC}_{50}$ values were calculated from the dose-response curve.

control mice, there was no fragmented band, whereas smeared and fragmented DNA bands were found in case of bark extracttreated EAC cells, shown in Figure 6(a). This may be due to chromatin condensation and nuclear fragmentation.

3.10. Modulation of Apoptotic Gene. RT-PCR analysis of the mRNA levels of p53, Bax (proapoptotic) and Bcl-2, NF- $\kappa \mathrm{B}$ (antiapoptotic) was performed to evaluate the expression of apoptosis genes (Figure 6). GAPDH (housekeeping gene) was used as control (Figure 6(c)). The figures represented the changes of apoptotic genes in treated and untreated cells. p53 is a tumor suppressor gene that is overexpressed in bark extract-treated cells at the $450 \mathrm{bp}$ position on the gel; also, the expression of Bax (proapoptotic) gene is increased by treatment with bark extract at the 500 bp position on the gel. Bcl-2 gene expression in cells treated with bark extract was reduced compared to control at $250 \mathrm{bp}$ position on the gel which was shown in Figure $6(\mathrm{f})$. Similarly, NF- $\kappa B$ was overexpressed in control at $125 \mathrm{bp}$ position on the gel, whereas it was downregulated in bark extract-treated cells.

3.11. Brine Shrimp Lethality Bioassay. The $\mathrm{LD}_{50}$ value of bark extract was calculated using probit analysis. Results of the lethality bioassay have been tabulated in Supplementary Table (S1). The extract showed $\mathrm{LD}_{50} 391.539 \mu \mathrm{g} / \mathrm{ml}$ in probit analysis, which is shown as Supplementary Figure 1 (S2). The lower $\mathrm{LD}_{50}$ means higher toxicity. The result proves that bark extract of $A$. augusta exhibits low toxic effects against brine shrimp nauplii in comparison to EAC cells.

3.12. ADMET. Physiochemical characteristics of a compound can be valid alternative to experimental method. In order to propose a compound to be drug, it has to maintain certain criteria. Here we predicted pharmacological and pharmacokinetics properties of the chemical compound of A. augusta. Therefore, admetSAR and SwissADME web servers were used to determine whether the ligand has any toxic profile by evaluating the physiological profile. This prediction method involves blood-brain barrier, human intestinal absorption, P-gp inhibitor, subcellular localization, hERG profile, AMES toxicity, carcinogen, and Lipinski's rule of five of the selected compound. ADMET filtering showed that four chemical compounds of $A$. augusta had carcinogenic effect and did not follow Lipinski's rule of five ( $\mathrm{H}$-bond donors $<5, \mathrm{H}$-bond acceptors $<10$, $\mathrm{MW}<500$ dalton, $\mathrm{C} \log p>5$, rotatable bond $<5$ ) (Table 8 ). To be administered as drugs, all compounds must have no carcinogenic effect and pass the Lipinski filtering [44]. However, two chemical compounds, 3,4-dihydroxybenzoic acid and vanillic acid, showed positive response to bloodbrain barrier, which indicates that all drugs will go through blood-brain barrier. These two compounds had weak inhibition of the human ether-a-go-go-related gene (hERG). Complete inhibition of hERG gene leads to long QT syndrome, so further study on this aspect is required [45]. P-glycoprotein (P-gp) functions as drug transporter, so clarification of the ligand noninhibitory activity towards $\mathrm{P}-\mathrm{gp}$ is required. Both ligand molecules had noninhibitory activity towards P-gp, which confirms positive attributes of the ligand. Oral bioavailability confirms the efficacy of the compound.

3.13. Docking. In the present study, the following PubChem CIDs were denoted as D1, D2, and D3: 72[IUPAC name: 3,4dihydroxybenzoic acid]; 8468[IUPAC name: 4-hydroxy-3- 
TABLE 7: Effect of bark extract of $A$. augusta on EAC cell growth in mice (in vivo).

\begin{tabular}{lccc}
\hline Name of experiment & Dose (mg/kg b. wt./day, i.p.) & Viable EAC cells on day 6 after inoculation & \% of cell growth inhibition \\
\hline EAC + control & - & $2.675 \pm 0.1890 \times 10^{6}$ & - \\
EAC + bleomycin & 0.3 & $0.423 \pm 0.0516 \times 10^{6}$ & 84.143 \\
EAC + A. augusta & 50 & $1.21 \pm 0.1897 \times 10^{6}$ & 54.9 \\
EAC + A. augusta & 100 & $0.65 \pm 0.0894 \times 10^{6}$ & 75.5 \\
\hline
\end{tabular}

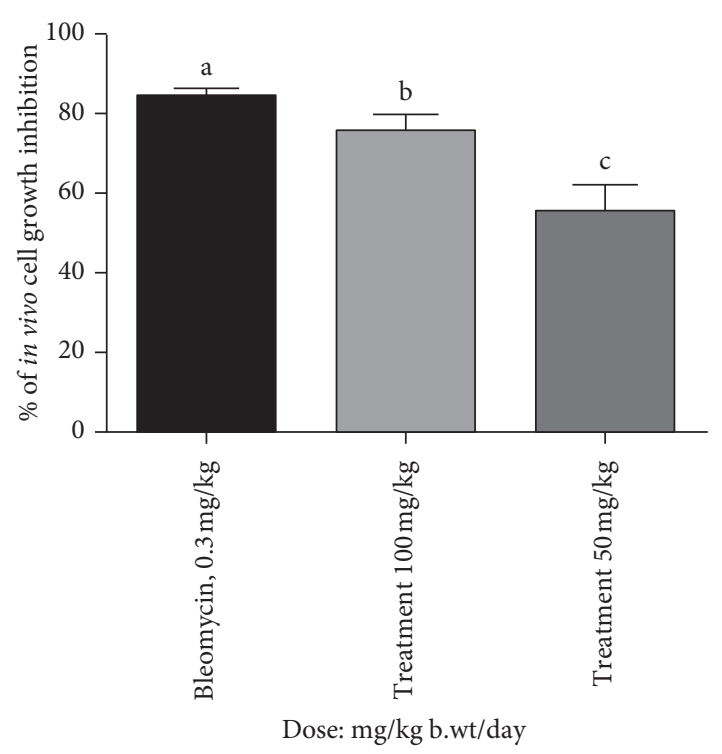

FIGURE 3: In vivo comparison of cell growth inhibition of EACbearing mice treated with different doses of bark extract of $A$. augusta. Significant cell growth inhibition was observed in EAC cells in response to $50 \mathrm{mg} / \mathrm{kg} /$ day and $100 \mathrm{mg} / \mathrm{kg} /$ day of A. augusta extract when compared with standard (bleomycin). Data were expressed in mean \pm SD (Table 6) at ${ }^{*} p<0.05(n=6)$ significant level.

methoxybenzoic acid]; and 11228183 [IUPAC name: 3-[[2[2-[2-[[(2S,3R)-2-[[(2S,3S, 4R)-4-[[(2S,3R)-2-[[6-amino2-[(1S)-3-amino-1-[[(2S)-2,3-diamino-3-oxopropyl]amino]3-oxopropyl]-5-methylpyrimidine-4-carbonyl]amino]-3-[(2R, $3 \mathrm{~S}, 4 \mathrm{~S}, 5 \mathrm{~S}, 6 \mathrm{~S})-3-[(2 \mathrm{R}, 3 \mathrm{~S}, 4 \mathrm{~S}, 5 \mathrm{R}, 6 \mathrm{R})-4$-carbamoyloxy-3,5dihydroxy-6-(hydroxymethyl)oxan-2-yl]oxy-4,5-dihydroxy-6(hydroxymethyl)oxan-2-yl]oxy-3-(1H-imidazol-5-yl)propanoyl] amino]-3-hydroxy-2-methylpentanoyl] amino]-3-hydroxybutanoyl] amino] ethyl]-1,3-thiazol-4-yl]-1,3-thiazole-4carbonyl]amino]propyl-dimethylsulfanium]. On the other hand, PubChem CIDs 247, 305, 73170, and 73659 were excluded from docking study as they show carcinogenic properties in ADMET filtering process.

Total internal energy, total intramolecular energy, and torsional free energy minus energy of unbound system summed up the binding energy in docking study. In AutoDock Vina, based on the binding energy value, the top nine conformers were generated for each docked complex [37]. Among these conformers, the lowest binding energy was considered as the most favorable docking pose. The docking energy of ligand molecules and NF- $\kappa \mathrm{B}$ protein in AutoDock Vina was D1: $-7.2 . \mathrm{kcal} / \mathrm{mol}, \mathrm{D} 2:-7.9 \mathrm{kcal} / \mathrm{mol}$, and D3: $-7.8 \mathrm{kcal} / \mathrm{mol}$ (Figure $6(\mathrm{a})$ ); for $\mathrm{Bcl}-2$ protein binding affinity was $-7.9,-8.1$, and $-7.7 \mathrm{kcal} / \mathrm{mol}$ (Figure 6(b)), respectively, for D1, D2, and D3.

D1 compound showed binding energy of $-7.2 \mathrm{kcal} / \mathrm{mol}$ by forming five hydrogen bonds at Asn103, His110, Ser211, Val212, and Arg214. Two hydrophobic bonds were also present at Val213 and Met208 for D1 and NF- $\kappa$ B protein complex. On the other hand, D2 and NF- $\kappa \mathrm{B}$ complex were stabilized by hydrogen bond at Ser113, Arg157, and His112 position and hydrophobic bond at Leu143 and Val145 residue. Bleomycin compound formed multiple hydrogen bonds with NF- $\kappa$ B protein at Ser249, Asn250, Asp274, Gly69, Lys80, Ser74, and Lys52 position and four hydrophobic bonds were seen at Gly55, Glu344, Lys79, and Lys80 residues.

On the other hand, three chemical compounds showed better energy while interacting with $\mathrm{Bcl}-2$ protein. D1 and Bcl-2 complex had binding energy of $-7.9 \mathrm{kcal} / \mathrm{mol}$ by forming three hydrogen bonds at Arg86, Trp135, and Glu138 and two hydrophobic bonds at Phe89 and Ala90. D2 compound also formed three hydrogen bonds with Bcl-2 protein at Ala90, Trp135, and Glu138 residue and two hydrophobic bonds were found at Phe89 and Ala90. However, D3 or bleomycin and protein complex were stabilized by three hydrogen bonds at Asn102, Gly104, Tyr161, and Leu160 and a hydrophobic bond at Phe63, Tyr67, Ala108, Ala59, Val107, Arg105, and Arg108 position (Figure7).

\section{Discussion}

Phytochemicals like alkaloids, glycosides, terpenoids, steroids, and flavonoids have anticancer activity. Comprehensive review has been done on the ability of antioxidant compounds to repel various human cancers [46]. Phenolics and flavonoids are the most abundant antioxidants found in the plant kingdom, and a number of plant species rich in phenolics and flavonoids reportedly have high therapeutic efficiency for the treatment of cancer [47]. In this investigation, we found that the bark extract of A. augusta is a rich source of phenolic and flavonoid compounds that can be used to treat various ailments.

The free radicals can initiate chain reactions and can cause cell death. Antioxidants accomplish these chain reactions by removing free radical intermediates and inhibit other oxidation reactions. Recent biological studies suggest that antioxidant rich plants can induce apoptosis of cancer cells in case of cancer (e.g., breast, liver, and colon) $[48,49]$. Our result demonstrates that the methanolic bark extract of A. augusta has significant antioxidant activity with $\mathrm{IC}_{50}$ value of $38.65 \mu \mathrm{g} / \mathrm{ml}$ when compared with standard BHT $\left(\mathrm{IC}_{50}\right.$ value $\left.57.29 \mu \mathrm{g} / \mathrm{ml}\right)$. 


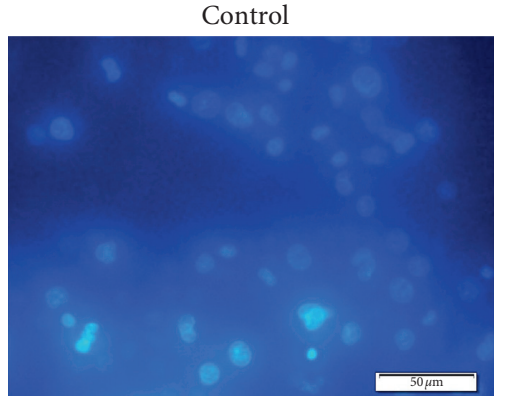

(a)

Control

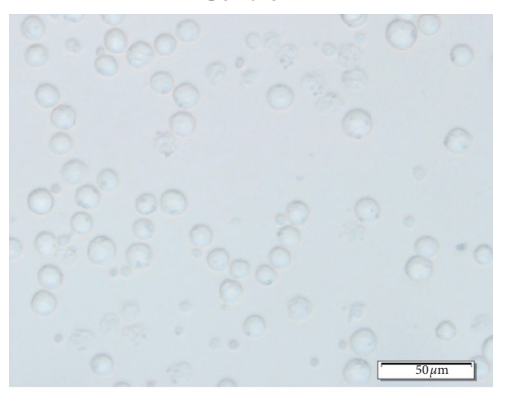

(d)

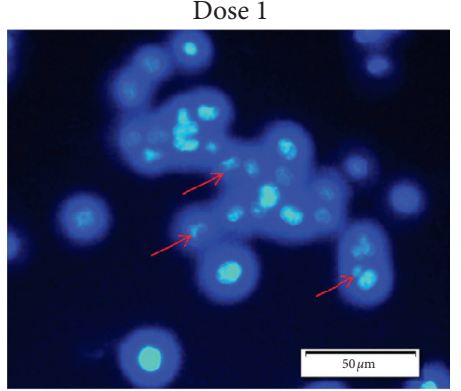

(b)

Dose 1

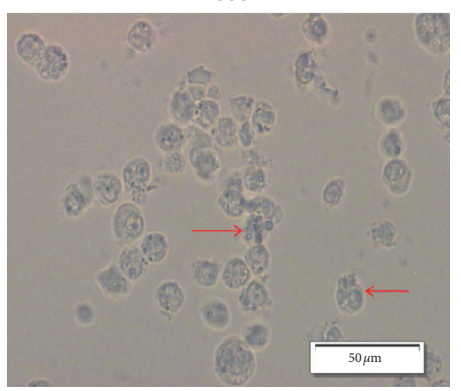

(e)

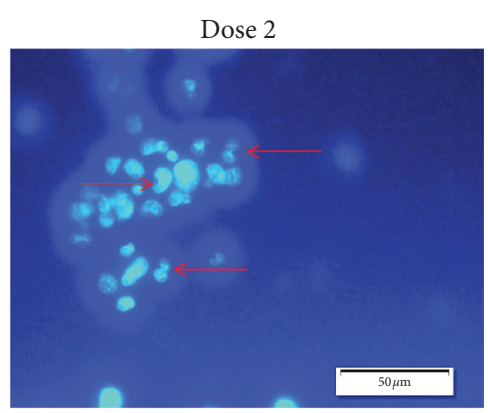

(c)

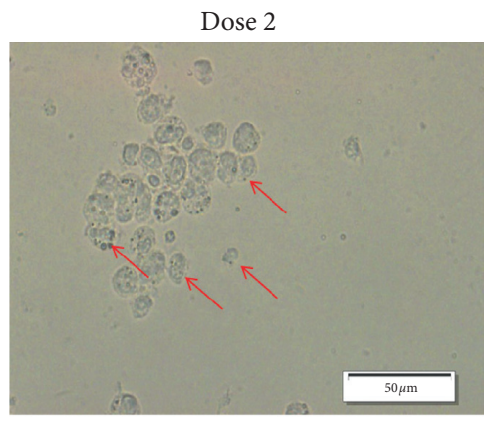

(f)

Figure 4: Fluorescence and optical detection of apoptosis using DAPI staining in untreated and treated EAC cells. Regular uniform shape of the cells was found in control in (a) fluorescence microscopy and (b) optical microscope. EAC cells treated with bark extract (100 mg/kg) of A. augusta and stained with DAPI in (c) fluorescence microscopy and (d) optical microscope showed apoptotic features indicated by arrows. At $200 \mathrm{mg} / \mathrm{kg}$ bark extract-treated EAC cells revealed similar changes in (e) fluorescence microscopy and (f) optical microscope.

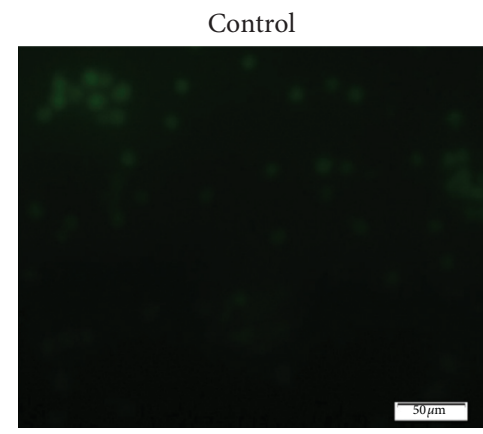

(a)

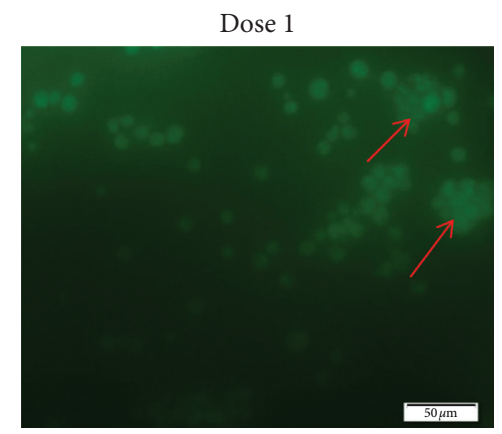

(b)

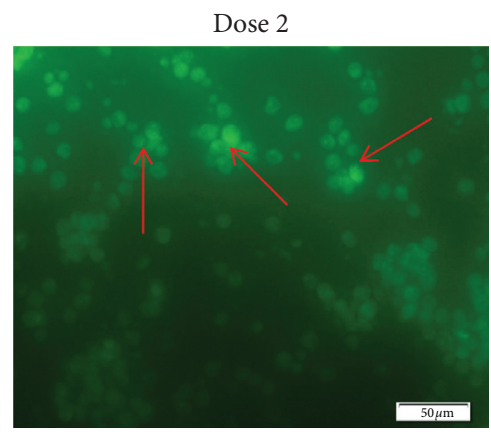

(c)

FIgURE 5: ROS generation in EAC cells treated with bark extract of A. augusta. (a) The dark staining of nuclei means that the intracellular generation of ROS was found in control. (b) A large number of EAC cells showed light staining for ROS (arrows) after treating EAC cells with $50 \mathrm{mg} / \mathrm{kg}$ bark extract of A. augusta. (c) An intense staining formation of ROS observed in EAC cells treated with $100 \mathrm{mg} / \mathrm{kg}$ bark extract of A. augusta.

In this study the cytotoxicity of the bark extract of $A$. augusta was reckoned against Ehrlich ascites carcinoma (EAC) cells at the concentration of $31.25-500 \mu \mathrm{g} / \mathrm{ml}$ and showed promising cell growth inhibition. The $\mathrm{IC}_{50}$ value was calculated for the extract $(329.41 \mu \mathrm{g} / \mathrm{ml})$ (Figure 2). To check whether the extract is too much toxic to the normal cells, the brine shrimp lethality bioassay was carried out. Probit analysis of the bioassay shows that the toxicity of the extract is comparatively low compared to that to the EAC cells.

In vivo anticancer activity of the bark extract was assessed by using EAC cell-bearing mouse model, and the result was compared with a reference standard drug named bleomycin $(0.3 \mathrm{mg} / \mathrm{kg})$. The numbers of viable cells were found to be decreased by around $75.5 \%$ at dose $100 \mathrm{mg} / \mathrm{kg}$ body weight (i.p.). In this study, untreated EAC cell-bearing mice gained rapid tumor growth, but the bark extracttreated EAC cell-bearing mice exhibited cell growth inhibition significantly.

Apoptosis is a cell suicidal mechanism that can be regulated by numerous cellular signaling pathway characterized morphologically by cell shrinkage, membrane blebbing, chromatin condensation, apoptotic body formation, etc. [28]. Treated and control EAC cells stained with DAPI dye under fluorescence microscope observation 


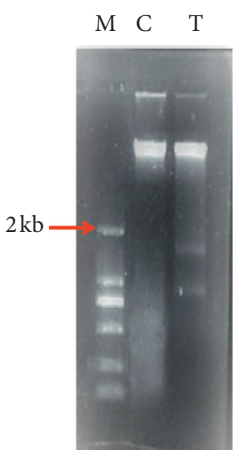

(a)

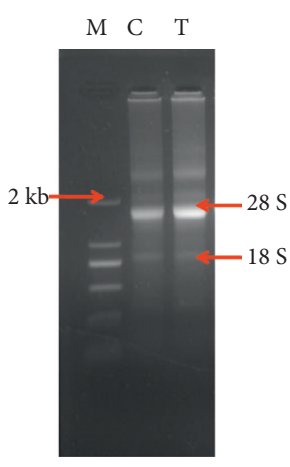

(b)

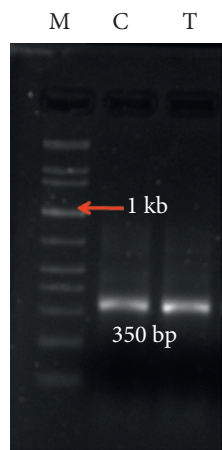

(c)

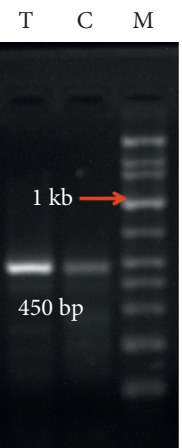

(d)

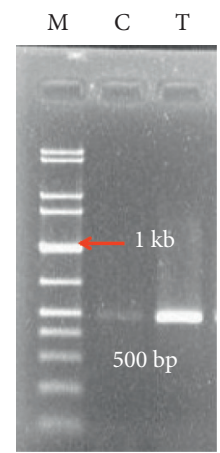

(e)

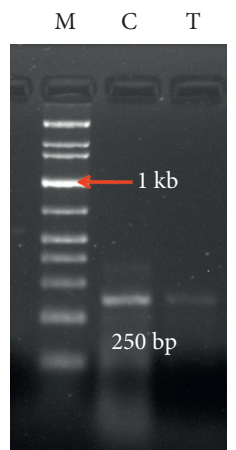

(f)

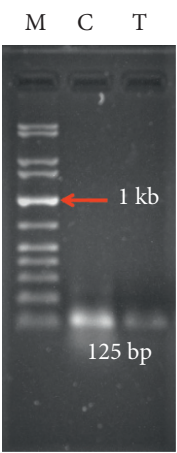

(g)

FIGURE 6: Different expression of proapoptotic and antiapoptotic genes by semiquantitative RT-PCR. Lanes (M), (C), and (T) represent molecular marker, control, and bark extract-treated cells, respectively. In (a) and (b), DL2000 DNA marker (Hubein Aibo Technology Co. Ltd.) was used, and in (c)-(g), $1 \mathrm{~kb}$ plus DNA ladder (TIANGEN Biotech Co., Ltd.) was used. (a) Fragmentation of genomic DNA in EAC cells treated with $100 \mathrm{mg} / \mathrm{kg}$ b.wt of A. augusta bark extract for 5 consecutive days. (b) Isolated RNA exhibited two separate bands as $28 \mathrm{~S}$ and 18S. (c) GAPDH (housekeeping gene) expression as a control. (d, e) The upregulation of the proapoptotic genes p53 and Bax compared to control. (f, g) The downregulation of the antiapoptotic genes Bcl-2 and NF- $\kappa \mathrm{B}$ in case of treated cells compared to control.

TABle 8: Predicted pharmacological and pharmacokinetics properties of selected A. augusta chemical compounds; here only two compounds passed the Lipinski filtering and toxicity scale.

\begin{tabular}{|c|c|c|c|c|c|c|}
\hline Parameter & CID-72 & CID-247 & CID-305 & CID-8468 & CID-73170 & CID-73659 \\
\hline Blood-brain barrier & $0.6376(-)$ & $0.9463(+)$ & $0.9214(+)$ & $0.5146(-)$ & $0.9618(+)$ & $0.6673(+)$ \\
\hline $\begin{array}{l}\text { Human intestinal } \\
\text { absorption }\end{array}$ & $0.8811(+)$ & $0.8819(+)$ & $0.9640(-)$ & $0.9231(+)$ & $1(+)$ & $0.9770(+)$ \\
\hline P-gp inhibitor & $\begin{array}{c}0.9948 \\
\text { Noninhibitor }\end{array}$ & $\begin{array}{c}0.9694 \\
\text { Noninhibitor }\end{array}$ & $\begin{array}{c}0.9540 \\
\text { Noninhibitor }\end{array}$ & $\begin{array}{c}0.9165 \\
\text { Noninhibitor }\end{array}$ & $\begin{array}{c}0.7670 \\
\text { Noninhibitor }\end{array}$ & $\begin{array}{c}0.8907 \\
\text { Noninhibitor }\end{array}$ \\
\hline $\log p$ & 0.65 & -1.69 & -1.38 & 1.08 & 7.05 & 5.24 \\
\hline hERG Inhibitor & $\begin{array}{c}0.9508 \\
\text { Noninhibitor }\end{array}$ & $\begin{array}{c}0.9340 \\
\text { Noninhibitor }\end{array}$ & $\begin{array}{c}0.8071 \\
\text { Noninhibitor }\end{array}$ & $\begin{array}{c}0.9545 \\
\text { Noninhibitor }\end{array}$ & $\begin{array}{c}0.7513 \\
\text { Noninhibitor }\end{array}$ & $\begin{array}{c}0.7017 \\
\text { Noninhibitor }\end{array}$ \\
\hline AMES toxicity & $\begin{array}{c}0.9326 \\
\text { Non AMES toxic }\end{array}$ & $\begin{array}{c}0.9331 \\
\text { Non AMES } \\
\text { toxic }\end{array}$ & $\begin{array}{c}0.9386 \\
\text { Non AMES } \\
\text { toxic }\end{array}$ & $\begin{array}{c}0.9419 \\
\text { Non AMES toxic }\end{array}$ & $\begin{array}{c}0.8996 \\
\text { Nontoxic }\end{array}$ & $\begin{array}{c}0.9087 \\
\text { AMES toxic }\end{array}$ \\
\hline Carcinogen & $\begin{array}{c}0.9154 \\
\text { Noncarcinogens }\end{array}$ & $\begin{array}{c}0.7504 \\
\text { Carcinogens }\end{array}$ & $\begin{array}{c}0.5996 \\
\text { Carcinogens }\end{array}$ & $\begin{array}{c}0.9046 \\
\text { Noncarcinogens }\end{array}$ & $\begin{array}{c}0.9227 \\
\text { Noncarcinogens }\end{array}$ & $\begin{array}{c}0.9552 \\
\text { Noncarcinogen }\end{array}$ \\
\hline Molecular weight & 154.12 & 117.15 & 104.17 & 168.15 & 426.73 & 472.70 \\
\hline Num. rotatable bonds & 1 & 2 & 2 & 2 & 0 & 1 \\
\hline Hydrogen bond acceptors & 4 & 2 & 1 & 4 & 1 & 4 \\
\hline Hydrogen bond donors & 3 & 0 & 1 & 2 & 1 & 3 \\
\hline Molar refractivity & 37.45 & 28.35 & 29.69 & 41.92 & 135.14 & 137.82 \\
\hline TPSA & 77.76 & 40.13 & 20.23 & 66.76 & 20.23 & 77.76 \\
\hline Lipinski & Yes & No (1 violat & Yes & Yes & No (1 violation) & No (1 violation) \\
\hline Bioavailability & 0.56 & 0.55 & 0.55 & 0.55 & 0.55 & 0.56 \\
\hline
\end{tabular}

showed different morphological changes which positively indicate the apoptosis of EAC cells treated with bark extract. It was strongly believed that cleavage of the chromosomal DNA into small fragment is the hallmark of the apoptosis [50]. We obtained smeared and fragmented band in $1 \%$ agarose gel in case of treated EAC cells that may be responsible for the occurrence of apoptosis, which might have taken place due to the presence of a protein called DNA fragmentation factor (DFF) shown by Wang and colleagues [51]. This could be due to the chromatin condensation and nuclear fragmentation, so this observation strongly proves that the cytotoxicity of bark extract occurred via apoptosis of the cancer cells.

Various genes are involved in the control of cell cycle, and upregulation or downregulation of particular gene can help in regaining the control of cell cycle in cancer cells, which can lead them to programmed cell death and limit cancer growth. Difference in expression level of p53, Bax, $\mathrm{Bcl}-2$, and NF- $\kappa \mathrm{B}$ in treated and control cells is shown in Figure 6 . The results of our study effectively suggest that the bark extract promotes the expression of p53 gene and inhibits the expression of Bcl-2 gene. The activation of tumor suppressor protein typically demonstrated the apoptosis of EAC cells treated with $A$. augusta bark extract, while the downregulation of $\mathrm{Bcl}-2$ gene increased the expression of Bax, which promotes cell death; however, when Bcl-2 dominates, the apoptotic pathway is inhibited and cells survive [24, 52]. Again the expression of NF- $\kappa$ B was downregulated in case of bark extract-treated cells similar to 


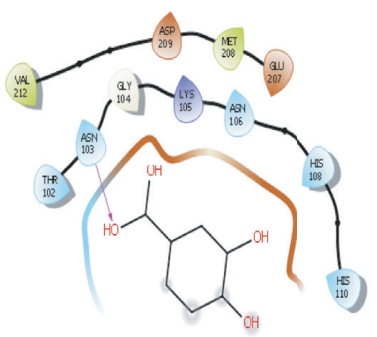

D1
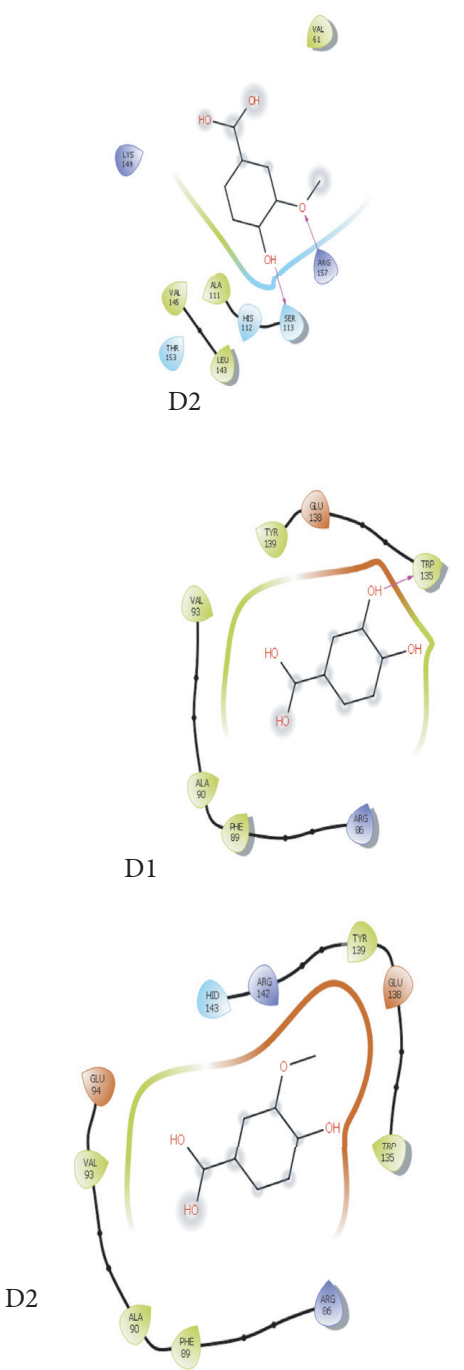

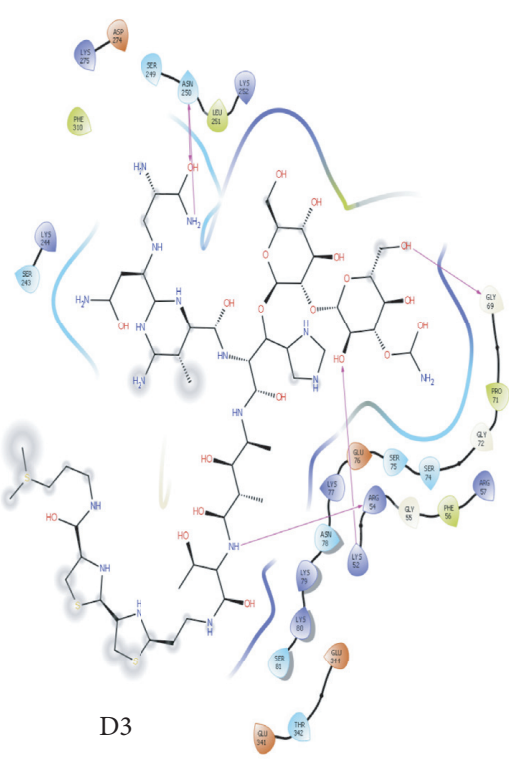

(a)

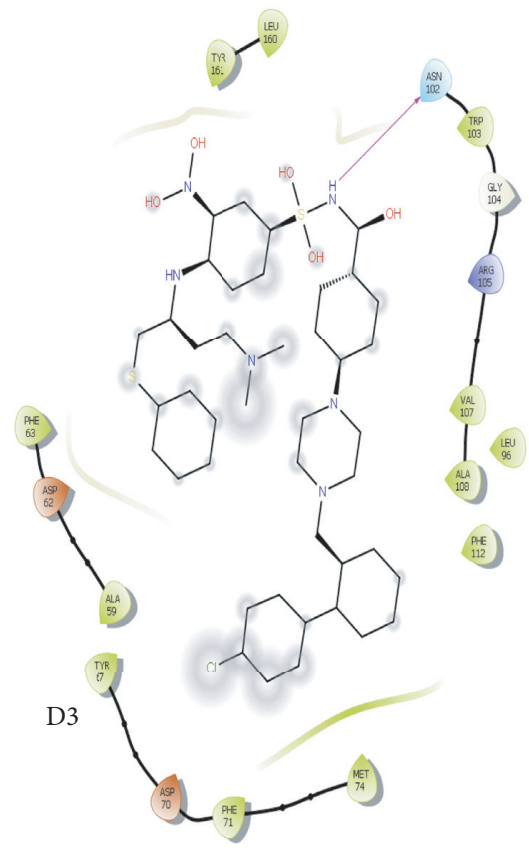

(b)

Figure 7: (a) Nonbonded interaction of NF- $\kappa$ B with D1, D2, and D3. (b) Binding pose and interaction diagram of all Bcl-2 docked complexes.

the downregulation of Bcl-2 which is also known to have supportive role in case of inhibition of cellular apoptosis [53]. The apoptosis induced by the bark extract of A. augusta in EAC cells was associated with upregulation of p53 expression mediated by inactivation of NF- $\kappa \mathrm{B}$ and production of ROS. According to previous studies, the production of intracellular ROS activated the downstream production of p53, which is a mitochondria-mediated pathway and consequently leads to apoptotic cell death $[54,55]$.
The polypharmacological profile of chemical compounds with the ability to target multiple biological signaling systems could be beneficial for treating complex diseases. Absorption, blood-brain barrier penetration, and bile elimination of chemical compounds can depend on the MW profile of ligand molecules. On the other hand, the $\log p$ value or lipophilicity profile of the ligand is pivotal for determining potency and several pharmacological parameters. Permeability can be decreased when lipophilicity value 
becomes too low, whereas metabolism is more likely to be compromised at high lipophilicity value. Therefore, carcinogenic profile and Lipinski need to be carefully assessed to declare the chemical compound as a lead molecule $[56,57]$. Two compounds of $A$. augusta passed pharmacological filtering and can be targeted in the future for further research.

Ligand protein binding is thought to be facilitated by the hydrogen bonding pattern in a biological system. Although the contribution of hydrogen bond to molecular function is not well understood, the presence of hydrogen bond can significantly improve the binding energy of protein and ligand complex [58-60]. Lastly, we found that among three ligands (including bleomycin), D2 exhibited the most potent anticancer activity against $\mathrm{Bcl}-2$ and $\mathrm{NF}-\kappa \mathrm{B}$ by showing binding affinity $(-7.9,-8.1)$. D2 or vanillic acid created strong noncovalent interaction at Ala90 which is near to the active sites of Bcl-2 protein (Val90, Glu95, Glu96). Based on the binding energy, this result suggests that D2 or vanillic acid may have the capacity to interfere with $\mathrm{Bcl}-2$ and $\mathrm{NF}-\kappa \mathrm{B}$ which ultimately can lead to further investigation of the $A$. augusta compound. Vanillic acid or D2 compound has been reported in the prevention of alternation of ion channels and cardiomyocyte death in mice, with antifungal, antimicrobial, and acetylcholinesterase inhibitory activities. Interestingly, derivatives of vanillic acid can act as immunosuppressive agents, and the molecular modeling profile was explored [61-63].

Bcl-2 can be overexpressed in various types of solid cancer and prevents apoptosis induced by a protective cell signaling mechanism. Furthermore, oligomerization prevention and apoptosis cascade initiation can be provided by the $\mathrm{BH} 3$ domain of $\mathrm{Bcl}-2$ protein. The natural phenolic compound 3,4-dihydroxybenzoic acid or protocatechuic acid can be used as a protective agent against neoplasm and is mostly associated with antioxidant activity [62]. Protocatechuic acid or D1 has been recently reported to inhibit $\mathrm{Bcl}-2$ protein expression and retinoblastoma phosphorylation in human leukemia cells [64]. Generally, NF- $\kappa \mathrm{B}$ translocates in the nucleus from cytoplasm by LPS (lipopolysaccharides) stimulation and, thus, transcription of inflammatory mediators induced by NF- $\kappa \mathrm{B}$ in the nucleus [64-69]. However, the impact of protocatechuic acid on LPS-induced NF- $\kappa \mathrm{B}$ suggests that PA can inhibit NF- $\kappa \mathrm{B}$ in BV2 microglia cells. Besides, LPS-induced TLR4 activation was suppressed by protocatechuic acid which is ultimately responsible for $\mathrm{NF}-\kappa \mathrm{B}$ inhibition by $\mathrm{D} 1$ or protocatechuic acid [70].

This combinatorial approach will aid fellow researchers in isolating compounds from Abroma augusta and getting more view for desirable consideration in future investigation.

\section{Conclusion}

In this study, we tried to provide fruitful evidence supporting the toxicity of A. augusta to EAC cells. Again, the results derived from this study strongly proves that $A$. augusta bark extract can induce EAC cells apoptosis through the activation of p53, Bax and also the suppression of NF- $\kappa \mathrm{B}$, $\mathrm{Bcl}-2$. The apoptotic effect of methanolic extract against EAC cells is attributed to its antioxidant activity and high phenolic and flavonoid contents. Further, activity of the chemical compound found in A. augusta through docking simulation has shown positive effect against $\mathrm{Bcl}-2$ and NF$\kappa \mathrm{B}$. However, in vitro and in vivo studies on the probable active compounds of this plant responsible for the above activities are still required to be investigated.

\section{Data Availability}

The data used to support the findings of this study are available from the corresponding author upon request.

\section{Conflicts of Interest}

The authors declare that they have no conflicts of interest.

\section{Supplementary Materials}

Supplementary Table S1: the mortality percentage of brine shrimp nauplii induced by methanolic bark extract of $A$. augusta. Supplementary Figure S2: the percentage of mortality of bark extract against different concentrations. (Supplementary Materials)

\section{References}

[1] A. R. David and M. R. Zimmerman, "Cancer: an old disease, a new disease or something in between?" Nature Reviews Cancer, vol. 10, no. 10, pp. 728-733, 2010.

[2] F. Bray, J. Ferlay, I. Soerjomataram, R. L. Siegel, L. A. Torre, and A. Jemal, "Global cancer statistics 2018: GLOBOCAN estimates of incidence and mortality worldwide for 36 cancers in 185 countries," CA: A Cancer Journal for Clinicians, vol. 68, no. 6, pp. 394-424, 2018.

[3] A. Desai, G. Qazi, R. Ganju et al., "Medicinal plants and cancer chemoprevention," Current Drug Metabolism, vol. 9, no. 7, pp. 581-591, 2008.

[4] S. C. Ghagane, S. I. Puranik, V. M. Kumbar et al., "In vitro antioxidant and anticancer activity of Leea indica leaf extracts on human prostate cancer cell lines," Integrative Medicine Research, vol. 6, no. 1, pp. 79-87, 2017.

[5] M. Riaz, M. Zia-Ul-Haq, and B. Saad, Anthocyanins and Human Health: Biomolecular and Therapeutic Aspects, Springer, Berlin, Germany, 2016.

[6] T. Tanaka, K. Miyazawa, T. Tsukamoto, T. Kuno, and K. Suzuki, "Pathobiology and chemoprevention of bladder cancer," Journal of Oncology., vol. 2011, Article ID 528353, 23 pages, 2011.

[7] S.-Y. Yin, N.-S. Yang, and T.-J. Lin, "Phytochemicals approach for developing cancer immunotherapeutics," Frontiers in Pharmacology., vol. 8, p. 386, 2017.

[8] S. Elmore, "Apoptosis: a review of programmed cell death," Toxicologic Pathology, vol. 35, no. 4, pp. 495-516, 2007.

[9] J. F. R. Kerr, A. H. Wyllie, and A. R. Currie, "Apoptosis: a basic biological phenomenon with wideranging implications in tissue kinetics," British Journal of Cancer, vol. 26, no. 4, pp. 239-257, 1972.

[10] A. Garg and B. Aggarwal, "Nuclear transcription factor- $\kappa \mathrm{B}$ as a target for cancer drug development," Leukemia, vol. 16, no. 6, pp. 1053-1068, 2002. 
[11] W. Jochum, E. Passegué, and E. F. Wagner, "AP-1 in mouse development and tumorigenesis," Oncogene, vol. 20, no. 19, pp. 2401-2412, 2001.

[12] M. A. Khan, M. M. Rahman, M. N. Sardar et al., "Comparative investigation of the free radical scavenging potential and anticancer property of Diospyros blancoi (Ebenaceae)," Asian Pacific Journal of Tropical Biomedicine, vol. 6, no. 5, pp. 410-417, 2016.

[13] E. Santharam, P. Ganesh, R. Soranam, V. V Divya, and P. L. NCJ, "Evaluation of in vitro free radical scavenging potential of various extracts of whole plant of Calycopteris floribunda (Lam)," Journal of Chemical and Pharmaceutical Research, vol. 7, no. 1, pp. 860-864, 2015.

[14] T. M. Lakshmi, R. Radha, and N. Jayshree, "In vitro antioxidant activity, total phenolic and total flavonoid content in extracts from the bark of Dalbergia sissoo roxb," International Journal of Pharma Science Research, vol. 5, no. 5, pp. 226-231, 2014.

[15] N. S. Chowdhury, F. Farjana, S. Jamaly, M. N. Begum, and M. E. A. Zenat, "Pharmacological values and phytochemical properties of devil's cotton (Ulatkambal) - a review," Bangladesh Pharmaceutical Journal, vol. 22, no. 1, pp. 109-116, 2019.

[16] R. Khanra, S. Dewanjee, T. K Dua et al., "Abroma augusta L. (Malvaceae) leaf extract attenuates diabetes induced nephropathy and cardiomyopathy via inhibition of oxidative stress and inflammatory response," Journal of Translational Medicine, vol. 13, no. 1, p. 6, 2015.

[17] P. Sunitha, N. Sathyanarayana, V. C. Suresh, S. Sreeramanan, J. S. Annie, and R. Xavier, "Phytochemical and antioxidant analysis of the leaf extract of Malaysian medicinal plant Abroma augusta L," Indian Journal of Pharmaceutical. Science., vol. 80, no. 1, pp. 192-198, 2018.

[18] A. Negi and A. Rawat, "Antihyperglycemic activity of root extracts of Abroma augusta Linn. on experimentally induced diabetic rats," International Journal of Pharmaceutical Research, vol. 10, no. 2, pp. 79-83, 2018.

[19] J. Bhandari, B. Muhammad, P. Thapa, and B. G. Shrestha, "Study of phytochemical, anti-microbial, anti-oxidant, and anti-cancer properties of Allium wallichii," BMC Complementary Alternative Medicine., vol. 17, no. 1, p. 102, 2017.

[20] A. Sofowora, "Screening plants for bioactive agents," $\mathrm{Me}$ dicinal Plants Traditional Medicine in Africa, vol. 2, pp. 134-156, 1993.

[21] L. Machu, L. Misurcova, J. Vavra Ambrozova et al., "Phenolic content and antioxidant capacity in algal food products," Molecules, vol. 20, no. 1, pp. 1118-1133, 2015.

[22] M. Kiranmai, C. B. M. Kumar, and I. Mohammed, "Comparison of total flavanoid content of Azadirachta indica root bark extracts prepared by different methods of extraction," Research Journal of Pharmaceutical, Biological and Chemical Sciences, vol. 2, no. 3, pp. 254-261, 2011.

[23] A. Matkowski and M. Piotrowska, "Antioxidant and free radical scavenging activities of some medicinal plants from the Lamiaceae," Fitoterapia, vol. 77, no. 5, pp. 346-353, 2006.

[24] A. H. M. K. Alam, "The antioxidative fraction of white mulberry induces apoptosis through regulation of p53 and $\mathrm{NF} \kappa \mathrm{B}$ in EAC cells," PLoS One, vol. 11, no. 12, Article ID e0167536, 2016.

[25] D. Lorke, "A new approach to practical acute toxicity testing," Archives of Toxicology, vol. 54, no. 4, pp. 275-287, 1983.

[26] S. Henkelman, G. Rakhorst, J. Blanton, and W. van Oeveren, "Standardization of incubation conditions for hemolysis testing of biomaterials," Materials Science and Engineering: C, vol. 29, no. 5, pp. 1650-1654, 2009.
[27] R. Zahan, "Design, synthesis and X-ray structural studies of novel [acetonitrile-benzyl-3-N-(2, 4 dihydroxyphenylmethylene) hydrazinecarbodithioato- $\left.\kappa 3-\mathrm{N}^{\prime}, \mathrm{S}, \mathrm{O}\right]$ nickel (1l) complex that potently inhibit cell proliferation through regulation of apoptosis related gene," Applied Organometallic Chemistry., vol. 33, no. 1, e4601 pages, 2019.

[28] S. R. Kabir, M. M. Nabi, M. Nurujjaman et al., "Momordica charantia seed lectin: toxicity, bacterial agglutination and antitumor properties," Applied Biochemistry and Biotechnology, vol. 175, no. 5, pp. 2616-2628, 2015.

[29] F. Islam, J. A. Khanam, M. Khatun et al., "Ap-Menth-1-ene4,7-diol (EC-1) from Eucalyptus camaldulensis Dhnh. Triggers apoptosis and cell cycle changes in Ehrlich ascites carcinoma cells," Phytotherapy Research, vol. 29, no. 4, pp. 573-581, 2015.

[30] F. Islam, H. Khatun, M. Khatun, S. M. M. Ali, and J. A. Khanam, "Growth inhibition and apoptosis of Ehrlich ascites carcinoma cells by the methanol extract ofEucalyptus camaldulensis," Pharmaceutical Biology, vol. 52, no. 3, pp. 281-290, 2014.

[31] M. Marvibaigi, "Antioxidant activity and ROS-dependent apoptotic effect of Scurrula ferruginea (Jack) danser methanol extract in human breast cancer cell MDA-MB-231," PLoS One, vol. 11, no. 7, Article ID e0158942, 2016.

[32] B. N. Meyer, N. R. Ferrigni, J. E. Putnam, L. B. Jacobsen, D. E. Nichols, and J. L. McLaughlin, "Brine shrimp: a convenient general bioassay for active plant constituents," Planta Medica, vol. 45, no. 5, pp. 31-34, 1982.

[33] S. Kim, P. A. Thiessen, E. E. Bolton et al., "PubChem substance and compound databases," Nucleic Acids Research, vol. 44, no. D1, pp. D1202-D1213, 2015.

[34] H. Land and M. S. Humble, "YASARA: a tool to obtain structural guidance in biocatalytic investigations," in Protein Engineering, pp. 43-67, Springer, Berlin, Germany, 2018.

[35] H. M. Berman, "The protein data bank," Nucleic Acids Research, vol. 28, no. 1, pp. 235-242, 2000.

[36] N. Guex and M. C. Peitsch, "SWISS-MODEL and the SwissPdb viewer: an environment for comparative protein modeling," Electrophoresis, vol. 18, no. 15, pp. 2714-2723, 1997.

[37] W. L. DeLano, "PyMOL," 2002.

[38] D. S. Goodsell, G. M. Morris, and A. J. Olson, “Automated docking of flexible ligands: applications of autodock," Journal of Molecular Recognition, vol. 9, no. 1, pp. 1-5, 1996.

[39] F. Cheng, W. Li, Y. Zhou et al., "admetSAR: a comprehensive source and free tool for assessment of chemical ADMET properties," Journal of Chemical Information and Modeling, vol. 52, no. 11, pp. 3099-3105, 2012.

[40] A. Daina, O. Michielin, and V. Zoete, "SwissADME: a free web tool to evaluate pharmacokinetics, drug-likeness and medicinal chemistry friendliness of small molecules," Scientific Reports., vol. 7, p. 42717, 2017.

[41] O. Trott and A. J. Olson, “AutoDock vina: Improving the speed and accuracy of docking with a new scoring function, efficient optimization, and multithreading," Journal of Computational. Chemistry., vol. 31, no. 2, pp. 455-461, 2010.

[42] D. Studio, Version 2.5; Accelrys, Inc., San Diego, CA, USA, 2009.

[43] D. Seeliger and B. L. de Groot, "Ligand docking and binding site analysis with PyMOL and Autodock/Vina," Journal of Computer-Aided Molecular Design, vol. 24, no. 5, pp. 417-422, 2010.

[44] M.-Q. Zhang and B. Wilkinson, "Drug discovery beyond the "rule-of-five" Current Opinion in Biotechnology, vol. 18, no. 6, pp. 478-488, 2007. 
[45] M. E. Curran, I. Splawski, K. W. Timothy, G. M. Vincen, E. D. Green, and M. T. Keating, "A molecular basis for cardiac arrhythmia: HERG mutations cause long QT syndrome," Cell, vol. 80, no. 5, pp. 795-803, 1995.

[46] A. M. Pisoschi and G. P. Negulescu, "Methods for total antioxidant activity determination: a review," Biochemistry Analytical Biochemistry, vol. 1, no. 1, p. 106, 2011.

[47] S. Singh, B. Sharma, S. S. Kanwar, and A. Kumar, "Lead phytochemicals for anticancer drug development," Frontiersin Plant Science., vol. 7, p. 1667, 2016.

[48] M. Deepa, T. Sureshkumar, P. K. Satheeshkumar, and S. Priya, "Antioxidant Rich Morus alba leaf extract induces apoptosis in human colon and breast cancer cells by the downregulation of nitric oxide produced by inducible nitric oxide synthase," Nutrition and Cancer, vol. 65, no. 2, pp. 305-310, 2013.

[49] A. Saxena, A. K. Saxena, J. Singh, and S. Bhushan, "Natural antioxidants synergistically enhance the anticancer potential of AP9-cd, a novel lignan composition from Cedrus deodara in human leukemia HL-60 cells," Chemico-Biological Interactions, vol. 188, no. 3, pp. 580-590, 2010.

[50] A. Wyllie, "Apoptosis (the 1992 frank rose memorial lecture)," British Journal of Cancer, vol. 67, no. 2, pp. 205-208, 1993.

[51] X. Liu, H. Zou, C. Slaughter, and X. Wang, "DFF, a heterodimeric protein that functions downstream of caspase- 3 to trigger DNA fragmentation during apoptosis," Cell, vol. 89, no. 2, pp. 175-184, 1997.

[52] C. Dai, B. Zhang, and X. Liu, "Pyrimethamine sensitizes pituitary adenomas cells to temozolomide through cathepsin b-dependent and caspase-dependent apoptotic pathways," International Journalof Cancer, vol. 133, no. 8, pp. 1982-1993, 2013.

[53] C. Borner, "The Bcl-2 protein family: sensors and checkpoints for life-or-death decisions," Molecular Immunology, vol. 39, no. 11, pp. 615-647, 2003.

[54] K. Kannan and S. K. Jain, "Oxidative stress and apoptosis," Pathophysiology, vol. 7, no. 3, pp. 153-163, 2000.

[55] B. Liu, Y. Chen, and D. K. S. Clair, "ROS and p53: a versatile partnership," Free Radical Biology and Medicine, vol. 44, no. 8, pp. 1529-1535, 2008.

[56] M. J. Waring, "Lipophilicity in drug discovery," Expert Opinion on Drug Discovery, vol. 5, no. 3, pp. 235-248, 2010.

[57] M. P. Gleeson, "Generation of a set of simple, interpretable ADMET rules of thumb," Journal of Medicinal Chemistry, vol. 51, no. 4, pp. 817-834, 2008.

[58] D. Chen, N. Oezguen, P. Urvil, C. Ferguson, S. M. Dann, and T. C. Savidge, "Regulation of protein-ligand binding affinity by hydrogen bond pairing," Science Advance, no. 3, 2016.

[59] J. Gao, D. A. Bosco, E. T. Powers, and J. W. Kelly, "Localized thermodynamic coupling between hydrogen bonding and microenvironment polarity substantially stabilizes proteins," Nature Structural \& Molecular Biology, vol. 16, no. 7, pp. 684-690, 2009.

[60] S. Salentin, V. J. Haupt, S. Daminelli, and M. Schroeder, "Polypharmacology rescored: protein-ligand interaction profiles for remote binding site similarity assessment," Progress in Biophysics and Molecular Biology, vol. 116, no. 2-3, pp. 174-186, 2014.

[61] S. C. Pendota, M. A. Aderogba, A. R. Ndhlala, and J. Van Staden, "Antimicrobial and acetylcholinesterase inhibitory activities of Buddleja salviifolia (L.) Lam. leaf extracts and isolated compounds," Journal of Ethnopharmacology, vol. 148, no. 2, pp. 515-520, 2013.

[62] M. Tognolini, C. Giorgio, I. Hassan Mohamed et al., "Perturbation of the EphA2-EphrinA1 system in human prostate cancer cells by colonic (poly)phenol catabolites," Journal of Agricultural and Food Chemistry, vol. 60, no. 36, pp. 88778884, 2012.

[63] P. S. M. Prince, K. Dhanasekar, and S. Rajakumar, "Vanillic acid prevents altered ion pumps, ions, inhibits Fas-receptor and caspase mediated apoptosis-signaling pathway and cardiomyocyte death in myocardial infarcted rats," ChemicoBiological Interactions, vol. 232, pp. 68-76, 2015.

[64] T.-H. Tseng, T.-W. Kao, C.-Y. Chu, F.-P. Chou, W.-L. Lin, and C.-J. Wang, "Induction of apoptosis by hibiscus protocatechuic acid in human leukemia cells via reduction of retinoblastoma (RB) phosphorylation and Bcl-2 expression," Biochemical Pharmacology, vol. 60, no. 3, pp. 307-315, 2000.

[65] Z. Ouyang, Z. Zhai, H. Li et al., "Hypericin suppresses osteoclast formation and wear particle-induced osteolysis via modulating ERK signalling pathway," Biochemical Pharmacology, vol. 90, no. 3, pp. 276-287, 2014.

[66] K. A. Harvey, C. L. Walker, Z. Xu et al., "Oleic acid inhibits stearic acid-induced inhibition of cell growth and pro-inflammatory responses in human aortic endothelial cells," Journal of Lipid Research, vol. 51, no. 12, pp. 3470-3480, 2010.

[67] Y.-F. Chuang, H.-Y. Yang, T.-L. Ko et al., "Valproic acid suppresses lipopolysaccharide-induced cyclooxygenase-2 expression via MKP-1 in murine brain microvascular endothelial cells," Biochemical Pharmacology, vol. 88, no. 3, pp. 372-383, 2014.

[68] O. L. German, S. Monaco, D. L. Agnolazza, N. P. Rotstein, and L. E. Politi, "Retinoid X receptor activation is essential for docosahexaenoic acid protection of retina photoreceptors," Journal of Lipid Research, vol. 54, no. 8, pp. 2236-2246, 2013.

[69] Y. Fu, Z. Wei, E. Zhou, N. Zhang, and Z. Yang, "Cyanidin-3O- $\beta$-glucoside inhibits lipopolysaccharide-induced inflammatory response in mouse mastitis model," Journal of Lipid Research, vol. 55, no. 6, pp. 1111-1119, 2014.

[70] H.-Y. Wang, H. Wang, J.-H. Wang, Q. Wang, Q.-F. Ma, and Y.-Y. Chen, "Protocatechuic acid inhibits inflammatory responses in LPS-stimulated BV2 microglia via NF- $\kappa \mathrm{B}$ and MAPKs signaling pathways," Neurochemical Research, vol. 40, no. 8, pp. 1655-1660, 2015. 